\title{
Wymiana barterowa jako strategia ubogich - między odwzajemnieniem a samowystarczalnością
}

Celem analizy jest próba interpretacji znaczeń nadawanych wymianie barterowej przez jej uczestników. Ramę interpretacyjną stanowią dwa konteksty teoretyczne: dyskurs odwzajemnienia i dyskurs samowystarczalności, w których ulokowałyśmy wypowiedzi badanych. Pierwszy z nich odsyła do strategii działania zakorzenionej w tradycjach i rytuałach gospodarki przedpieniężnej, drugi natomiast nawiązuje do klasycznej liberalnej wykładni człowieczeństwa, wypełniającego się w działaniach ukierunkowanych na pozyskiwanie niezależności od innych. Napięcia powstające między tymi strategiami wyjaśnia koncepcja szacunku Richarda Sennetta, zgodnie z którą jest on zyskiwany przez dawanie innym lub przez samorozwój. Analizowane interpretacje uczestników wymiany barterowej wskazują, że obydwie strategie są przez nich traktowane jako wzajemnie niesprzeczne sposoby wyjaśniania praktyk, w których biorą udział.

Słowa kluczowe: wymiana barterowa, bieda, odwzajemnienie, autonomia

Barter exchange as a strategy of the poor between reciprocity and self-sufficiency

The aim of the analysis is an attempt to interpret the meanings given to the barter exchange by its participants. The interpretative framework consists of two theoretical contexts: the discourse of reciprocity and the discourse of self-sufficiency in which we have placed the statements of the respondents. The former refers to the strategy rooted in tradition and rituals of barter economy, while the latter refers to the classical liberal interpretation of humanity fulfilled in actions aimed at gaining independence from others. The tensions between these strategies are explained by Richard Sennett's concept of respect where respect is earned by giving to others or through self-development. The analysed interpretations of

1 Uniwersytet Gdański; pedmlz@ug.edu.pl,1.strumska@ug.edu.pl. 
barter exchange participants indicate that they treat both strategies as mutually consistent ways of explaining the practices in which they participate.

Key words: barter exchange, poverty, reciprocity, autonomy

\section{Wprowadzenie}

Przedmiotem naszej analizy są znaczenia nadawane wymianie barterowej, która we współczesnym, zdominowanym przez kapitalizm finansowy świecie stanowi jedną z głównych alternatywnych praktyk ekonomicznych dostępnych ludziom ubogim, którzy utracili dostęp do pieniądza. Znaczenia, o których mowa, poddamy interpretacji w dwóch konkurencyjnych kontekstach teoretycznych: dyskursu odwzajemnienia i dyskursu samowystarczalności. Teoretyczną ramę stanowi dla nich Sennettowska koncepcja szacunku, budowanego na strategii wzajemności lub niezależności. Egzemplifikację napięcia między tymi dyskursami stanowią dla nas znaczenia nadawane wymianie barterowej przez kobiety w niej uczestniczące ${ }^{2}$.

\section{Wymiana barterowa - powrót do gospodarowania bez pieniądza w świecie pieniądza}

W kulturach pierwotnych podstawowym sposobem zbywania i nabywania dóbr oraz usług był barter, czyli wymiana przedmiotu za przedmiot/usługi za usługę. Towarzyszyły mu jednak niewygody, związane z trudnością określenia wartości wymienianych przedmiotów i usług czy też ze zrównoważeniem wartości wymienianych przedmiotów. System ten szybko został więc zastąpiony przez tzw. pośredników wymiany - dobra trwałe, podzielne i stosunkowo rzadko występujące (skóry, sól, zboże), które zostały potraktowane jako dobra konsumpcyjne, stanowiące pierwotną formę pieniądza. Stąd „pieniądz nie ma jednej ogólnie przyjętej definicji - zmieniały się one na przestrzeni lat $z$ uwagi na rozwój wymiany handlowej, ewolucję sposobu funkcjonowania gospodarki, przyjęte doktryny ekonomiczne, a przede wszystkim z powodu dóbr, które pełniły funkcję pieniądza. Najpierw były to dobra naturalne i monety mające własną wartość, poprzez papier, aż do pieniądza w postaci zapisu elektronicznego" (Piotrowska 2014: 278).

\footnotetext{
2 Wykorzystywane w tekście wypowiedzi pochodzą z szerszego materiału empirycznego, dotyczącego konstruowanych przez kobiety strategii radzenia sobie z biedą, zgromadzonego przez Elizę Rozalię Żuchlińską na potrzeby pracy magisterskiej. Badania o charakterze jakościowym z wykorzystaniem wywiadu narracyjno-biograficznego zostały przeprowadzone w 2016 r. na celowo dobranej grupie dziesięciu kobiet, pochodzących z jednej z położonych pod Gdańskiem wsi.
} 
Ten niezwykle użyteczny wynalazek od czasu swojego powstania pełni funkcje ekonomiczne (transakcyjną, obrachunkową, płatniczą, tezauryzacyjną) (Gruszecki 2004: 70) i funkcje społeczne (behawioralną, motywacyjną, informacyjną, integrującą i dezintegrującą). Z perspektywy podjętej przez nas problematyki szczególnie interesująca jest funkcja dezintegrująca, która dotyczy jego wpływu na struktury społeczne, polegająca na rozwarstwianiu społeczności na posiadających i nieposiadających. Niespotykane dotąd $w$ historii nasilenie tej funkcji pieniądza, z którym mamy obecnie do czynienia, jest związane z powstaniem współczesnego turbo kapitalizmu (Luttwak 2000) i jego finansowej odmiany, redukującej znaczenie produkcji na rzecz akumulacji zysków w postaci kapitału inwestycyjnego za pośrednictwem mechanizmów systemu finansowego. Znamienną cechą tej fazy rozwoju kapitalizmu są gwałtowne przeobrażenia struktury społecznej znaczone kolejnymi kryzysami finansowymi, po których pozostają ślady w postaci narastających nierówności dochodowych i coraz większych dysproporcji między bogatymi a biednymi. Bogaci są obecnie tak bogaci, że mają trudności ze skonsumowaniem swoich zasobów, a biedni są tak biedni, że nie tylko doświadczają niedoborów i mają kłopoty z zaspokajaniem swoich potrzeb, ale mają też coraz mniejszy dostęp do pieniądza (Reichel 2007: 10-12).

$\mathrm{Na}$ tle tych kierunków przemian współczesnego kapitalizmu rodzą się idee i teorie problematyzujące rolę pieniądza, rozumianego dotychczas głównie jako neutralne i użyteczne narzędzie pośredniczące w wymianie dóbr i usług. W miarę kumulacji pieniądza w górnej warstwie hierarchii społecznej, coraz częściej jest on postrzegany również jako najważniejszy instrument stratyfikacji społecznej, naznaczania i wykluczania nieposiadających.

Równolegle, w świecie, w którym mamy do czynienia z niezwykłym w historii nagromadzeniem pieniądza i równocześnie coraz trudniejszym do niego dostępem coraz większej liczby ludzi, powstają liczne alternatywne praktyki gospodarowania w warunkach deficytu pieniądza, a ludzie odkrywają, że pieniądz nie jest niezbędny do tego, by móc wymieniać się dobrami i usługami. Konieczność radzenia sobie z niedoborem pieniądza jest głównym impulsem dla rozwoju bezgotówkowych transakcji, czyli barteru (Reichel 2007: 31). Powstaje coraz więcej lokalnych walut, platform wymiany wirtualnej, której przykładami są LETS (Local Exchange Trading System) czy Banki Czasu (Reichel 2007: 13-55), składających się na tzw. alternatywną ekonomię.

Historia ekonomii alternatywnej sięga 1932 r., gdy swój urząd objął burmistrz małego miasteczka położonego w górach Tyrolu. Finanse miasta znajdowały się wówczas w głębokiej recesji, uniemożliwiającej bieżące funkcjonowanie miasta i jakiekolwiek inwestycje w infrastrukturę. Burmistrz ów wydrukował zatem tzw. freigeld - „wolne pieniądze”, którymi wynagradzał urzędników miejskich i pokrywał koszty prac publicznych (Wewiór, Jurkiewicz 2013). Od tego czasu w wielu 
miejscach świata (również w Polsce) drukowane są takie regionalne waluty uzupełniające i zastępujące pieniądz. Kolejnym krokiem w tworzeniu alternatywnego rynku stały się LETS-y i Banki Czasu, w których wymiana jest oparta na informacji. W przypadku LETS pierwszym krokiem do jego utworzenia jest zrzeszenie ludzi, sklepów i firm, które spisują swoje potrzeby i oferty. Na tej podstawie tworzy się wspólną bazę danych, która umożliwia kontakt i wymianę między członkami lokalnej lub nawet szerszej społeczności (Wewiór, Jurkiewicz 2013). Na podobnej zasadzie działają Banki Czasu, które gromadzą informacje o osobach bezgotówkowo oferujących innym swoje umiejętności. W ich przypadku jednostką rozliczeniową, niezależnie od rodzaju oferowanej usługi, jest zwykle godzina.

Popularność alternatywnej ekonomii pozostaje w bezpośrednim związku z sytuacją gospodarczą. Na przykład „w Wielkiej Brytanii w latach 1986-1991 działało zaledwie dziesięć systemów, jednak, gdy pod koniec 1992 r. dotknął ją kryzys, liczba LETS-ów zaczęła przyrastać w tempie geometrycznym. Podobny scenariusz obserwujemy w Nowej Zelandii, gdzie LETS-y (nazywane tu częściej Green Dollar Exchange lub Exchange and Barter Systems) rozwijały się na dużą skalę po 1987 r., gdy kraj zmagał się z wysokim bezrobociem, efektami krachu na giełdzie i światowej recesji" (Wewiór, Jurkiewicz 2013).

Pomimo tego, że w różnych regionach świata rozwinęły się różne praktyki barterowe, wkrótce okazało się, że nie wszystkie z nich są równie dostępne dla ludzi ubogich, co dla ludzi stosunkowo zamożnych. Niektóre z nich wymagają bowiem pewnej infrastruktury organizacyjnej czy przychylności władz lokalnych (pieniądz regionalny). Inne z kolei wymagają od uczestników pewnych warunków wstępnych w postaci komputera, szybkiego łącza i minimalnych kompetencji w zakresie ich obsługi (LETS) (Wewiór, Jurkiewicz 2013). Najbardziej dostępne dla ubogich są Banki Czasu, które stanowią odmianę barteru usługowego, polegającego na bezgotówkowej wymianie usług. Można je potraktować jako współczesną wersję dawnego wiejskiego odrobku, który jest praktycznie niewyczerpywalny, ponieważ na wsi zwykle nie brakuje zajęcia - „pracy do zrobienia”. Każdy zatem, niezależnie od zasobności swojego portfela, może coś dla kogoś zrobić (Szkudlarek 2005: 25-27).

Ekonomia alternatywna jest formą gospodarowania w świecie pieniądza ludzi, którzy są pozbawieni dostępu do niego. Pomimo wszelkich korzyści, które z niej wynikają, trzeba ją zatem traktować jako strategię ludzi wykluczonych ze względu na brak pieniądza $\mathrm{z}$ udziału $\mathrm{w}$ rynku zdominowanym przez pieniądz. Strategii tej, jak się okazuje, mogą być jednak przez jej użytkowników przydawane różne znaczenia: $\mathrm{z}$ jednej strony może być ona interpretowana jako zakorzeniona $\mathrm{w}$ dawnych czasach praktyka odwzajemnienia, z drugiej natomiast - jako liberalna co do swojego rodowodu praktyka uniezależniania się od innych. Pierwszej przypisujemy znaczenie dospołeczne, drugiej natomiast - odspołeczne. 


\section{Odwzajemnienie jako dospołeczna strategia radzenia sobie $\mathrm{z}$ biedą}

Dospołeczny sens praktyki odwzajemnienia daje się wywieść z Sennettowskiej teorii szacunku. Zgodnie z interpretacją tego autora, szacunek jest bowiem „fundamentalnym elementem doświadczania relacji społecznych, a także doświadczania siebie" (Sennett 2012: 57), zasadniczo jednak odmiennym od statusu, prestiżu czy też uznania. Status „określa położenie jednostki w hierarchii społecznej” (Sennett 2012: 61), prestiż „odsyła (...) do emocji, które status pobudza w innych ludziach” (Sennett 2012), a uznanie „oznacza respektowanie tych, którzy nie są nam równi” (John Rawls) (Sennett 2012: 62) lub „respektowanie poglądów jednostek, których interesy są sprzeczne z naszymi” (Jürgen Habermas) (Sennett 2012). Szacunek stanowi natomiast mentalną ramę, definiującą sposób rozumienia i konstruowania relacji międzyludzkich w kategoriach dospołecznych. Zdaniem Richarda Sennetta „społeczeństwo zbudowane jest na powszechnej zasadzie, wedle której traktując innych jak równych, umacniamy wzajemny szacunek" (2012: 9). Problem jednak tkwi w tym, że między ludźmi realnie występuje wiele nierówności o charakterze mniej lub bardziej arbitralnym. Powstaje zatem pytanie, czy wzajemny szacunek może dotyczyć także tych relacji, których uczestnicy ewidentnie nie są sobie równi. Odpowiedzi na to pytanie dostarcza analiza mechanizmów społecznego kształtowania ludzkich charakterów. Szacunek nie jest bowiem przynależny nikomu z natury rzeczy, lecz jest zdobywany na trzy sposoby: przez samorozwój, przez troskę o siebie i przez dawanie innym. Ostatni ze sposobów jest to „najbardziej bodaj uniwersalne, ponadczasowe i najgłębsze źródło szacunku" (Sennett 2012: 71), które jak żadna inna relacja dotyka uczuć innych ludzi, ponieważ u jego podstaw leży współczucie sprzyjające nawiązywaniu więzi społecznych. Wzajemność trzeba jednak odróżnić od zwykłego obdarowania kogoś, ponieważ dotyczy ona tych sytuacji, gdy nie tylko obdarowujemy, ale i jesteśmy obdarowywani. Zatem ,jeśli nie prosimy o nic w zamian, to pokazujemy, że nie uznajemy wzajemności w relacji z obdarowywaną przez nas osobą" (Sennett 2012: 226). Równość powstaje $\mathrm{w}$ tym kontekście na bazie wzajemności obdarowania, a nierówności - na skutek nieodwzajemnienia darów (Sennett 2012: 227).

Dokonująca się podczas odwzajemnienia „wymiana kieruje ludzi na zewnątrz" (Sennett 2012: 233), kształtując głęboko osadzany w przemianie dokonującej się w nich samych stosunek do innych. Kwintesencją owej przemiany jest uczucie szacunku, wzmagające zdolność do kooperowania z innymi i wytwarzania sieci relacji opartych na odwzajemnieniu. Wymiana (transakcja barterowa) przynosi zatem konkretne korzyści społeczne, które dalece wykraczają poza korzyści ekonomiczne, ponieważ wzmacnia wzajemny szacunek i więzi między ludźmi - biednymi i niebiednymi, między którymi zachodzą kontakty w warunkach 
równości obu stron, co nie byłoby możliwe w przypadku wykorzystania pieniądza jako pośrednika (lets.pl/korzyści.html). Relacje wzajemnościowe wytwarzają nieformalny kapitał społeczny, na bazie którego powstaje i rozwija się wspólnota (Reichel 2007: 58). Konstytutywne są dla niej akty wymiany, dokonywane między osobami, które pozostają ze sobą w bliskich relacjach. Otrzymanie czegoś od kogoś zobowiązuje do rewanżu. Udzielana pomoc postrzegana jest bowiem jako forma daru, który wymaga odwzajemnienia się, przy czym nie jest ważny jego ekwiwalentny charakter, ale sam fakt odwdzięczenia się przez osobę obdarowaną (Palska 2017: 183-184). Osoba obdarowana wie komu, kiedy i jak powinna się odwdzięczyć, ponieważ odczuwa silny przymus odwzajemnienia się (Szkudlarek 2005: 24). Dzięki temu poczucie zależności, tworzące się w momencie otrzymywania daru, zmienia się w szacunek dla samego siebie mocowany w zdolności do odwzajemnienia. Dar, który może zostać odwzajemniony czyni bowiem z potrzebującego - darczyńcę (Kudlińska 2012: 8).

W zgromadzonym materiale empirycznym zostały odnotowane tropy, które wskazują na przydawanie przez respondentki wymianie barterowej, w której biorą udział, takich właśnie dospołecznych sensów. Są one opisywane przez respondentki za pośrednictwem przysłówków: wzajemnie, nawzajem; oraz zaimków typu: wszyscy, nas, my. Te środki językowe pozwalają respondentkom definiować wymianę barterową jako wymianę dóbr materialnych, u której podłoża tkwi i równocześnie która inicjuje wymianę dóbr niematerialnych (troski, życzliwości, współczucia, uwagi, zainteresowania), a te z kolei są podstawą zawiązywania się wspólnoty („pozwala mi na to, żeby z ludźmi się spotykać, bo wiadomo, że jak coś zrobisz dla kogoś, to zawsze można z nim pogadać trochę"). Cechą specyficzną tak szeroko rozumianej wymiany jest jej osadzanie na trzech filarach: współdziałania, współpracy i wzajemnej komunikacji, które w odpowiedniej konfiguracji tworzą specyficzny rodzaj tzw. relacji spiralnej (spiral relationship) (Olivier 2009: 153-179). Ten rodzaj relacji pozwala ludziom dostrzec to, że zależą od siebie wzajemnie nie tylko w sensie materialnym, ale przede wszystkim w sensie wzajemnej wymiany emocji, znaczeń, pomysłów, wyobrażeń, tworzących podzielane pole semantyczne (Olivier 2009). W tym kontekście wspólnota jest nie tylko odkrywana przez ludzi, ale przede wszystkim jest przez nich aktywnie tworzona/kreowana (Olivier 2009). Ludzie czują się jej częścią („bo czuję się taka z ludźmi, z sąsiadami połączona, a nie taka odcięta"), silniej się z nią utożsamiają, identyfikują z jej członkami, a w konsekwencji mocniej troszczą się o wspólnie wytwarzane dobro i o siebie nawzajem („trzeba pamiętać o innych, co im tam potrzeba, bo jak się nie zadba o innych, to obce się nie zatroszczą. Swojego człowiek też sam nie upilnuje”). Jest to artykułowane w używanych przez respondentki wyrażeniach: „pomagać”, „dawać”, „zrobić coś dla kogos”, „nawzajem/wzajemnie”, które odsyłają do wytworzonej przez nie hierarchii wartości, w której troska o innych, uczciwość 
wobec nich, lojalność i solidarność zajmują czołowe miejsca (Carole 1995: 354, 413). Na bazie podzielanych wartości, poza światem pieniądza, ludzie budują poczucie równości i szacunku dla samych siebie:

I właśnie takie nawzajem sobie dawnie tego a tamtego, albo że ktoś dla kogoś coś zrobi, to daje taką możliwość też tym, co pieniędzy brakuje, żeby nie czuli się gorsi, bo jak pieniądze między ludzi „wchodzą”, to wtedy są gorsi i lepsi, bo jedni mają pieniądze, a drudzy nie. A jak się wymieniamy, to każdy jest drugiemu równy, bo jeden drugiemu zawsze coś może dać, a jak nie dać, to coś pójść zrobić, a już szczególnie na wsi, bo jak coś z ogródka nie dasz, to możesz iść w tym ogrodzie coś pomóc zrobić. (Respondentka 9)

Ja też mogę komuś pomóc. To nie jest tylko tak, że tylko mi pomagają, ja też to robię. Miło jest tak poczuć się potrzebnym i docenionym. Może dlatego, że mi też ludzie dziękują za pomoc, to ja też to robię, bo wiem, jakie to ważne i miłe. Ja bardzo się cieszę, że mam wokół siebie ludzi, którzy mi pomagają, że ja też komuś mogę pomóc. (Respondentka 4)

Konstruowany w odniesieniu do współdziałania i wzajemnej wymiany szacunek, nawiązując do jego sennettowskiej interpretacji, tworzy dla respondentek podłoże splatania rozproszonych relacji dospołecznych we wspólnotę:

Tutaj na wsi to jest podstawa życia. Tutaj to jest takie naturalne. I to bez znaczenia, czy ktoś jest biedny, czy bogaty. Po prostu ludzie na wsi tak żyją. Jeden drugiemu pomoże, bo ludzie się znają, tak po prostu trzeba. Tak tu jest od zawsze. (Respondentka 2)

To jest to, co kocham tu na wsi, to, że ludzie są dla siebie, że sobie pomagają. Ja to po prostu za to kocham tą moją wieś. My sobie tu naprawdę potrafimy sami poradzić, bo wystarczy mieć dobrych sąsiadów i samemu też być dla nich dobrym, to naprawdę można sobie poradzić, bo dobrzy sąsiedzi to podstawa. W miastach to ludzie się ukrywają w czterech ścianach, nie to co tu, bo tu wszyscy wychodzą do ludzi (...), bo my sobie pomagamy, bośmy tak nauczeni i w ogóle to dla nas takie normalne jest, że sąsiad sąsiadowi pomaga, a jak sąsiad biedny albo w potrzebie, to mu się po prostu pomaga. (Respondentka 10)

\section{Samowystarczalność jako odspołeczna strategia radzenia sobie $\mathrm{z}$ biedą}

W tej części tekstu naszym zamysłem jest poszukiwanie w wypowiedziach respondentek tropów wskazujących na pracę dyskursu samowystarczalności jako umocowania dla neoliberalnej koncepcji wolności (niezależności) jednostkowej, któremu przypisałyśmy walor inicjowania odspołecznych strategii radzenia sobie z biedą. 
Samowystarczalność (ekonomiczna) jest kategorią ujmowaną przez liberałów jako fundament ludzkiej niezależności od przymusu ze strony innych osób w sferze społecznej i politycznej, sprowadzaną przez nich do umiejętności pozyskania takiego zasobu własności, który pozwala jednostce podtrzymać swoje życie bez pomocy ze strony innych. Dla uzyskania dostępu do tak rozumianej niezależności konieczne są zdaniem liberałów odpowiednie okoliczności polityczne (prawnie zagwarantowana swoboda gospodarowania) i stosowne kompetencje jednostkowe (racjonalny umysł, zdolny trafnie oceniać relację cel-środek, dzięki której możliwe jest skuteczne działanie polegające na gromadzeniu własności). Kompetencje, o których mowa, zostały przypisane przez liberałów jedynie jednostce dojrzałej, która wydobyła się ze stanu dzieciństwa i definiującej dla niego nieracjonalności i w związku z nią - zależności od innych. Zgodnie ze źródłową dla współczesnego neoliberalizmu klasyczną doktryną liberalną, umocowana w racjonalności niezależność od innych jest zatem konstytutywną cechą ludzkiej dojrzałości, znamieniem wyjścia człowieka z niepełnoletniości, dla której charakterystyczna jest wynikająca z nieracjonalności zależność od innych. W odróżnieniu od pełnoletniości, „niepełnoletniość to niezdolność człowieka do posługiwania się własnym rozumem bez obcego kierownictwa" (Kant 2000: 194), wiodąca do zależności od innych w każdej sferze życia.

Pełnoletniość opisana w kategoriach racjonalności stała się stanem niekoniecznym, a jedynie możliwym, dlatego kategorię nieracjonalności można było zacząć wykorzystywać do charakteryzowania człowieka dorosłego, który z różnych względów sam uchyla się od korzystania ze swojego rozumu, w optyce zawinienia. Jak uważa Immanuel Kant, „zawinioną jest (...) niepełnoletniość wtedy, kiedy przyczyną jej jest nie brak rozumu, ale decyzji i odwagi posługiwania się nim bez obcego kierownictwa" (2000). Dla Kanta zatem o pełnoletniości decyduje nie tylko fakt racjonalności, ale również wola korzystania z niej, stąd świadome podtrzymywanie ponad miarę własnej niepełnoletniości z człowieka dorosłego czyni istotę podobną dziecku.

Dzięki kantowskiej interpretacji zawinionej nieracjonalności, liberałowie uzyskali narzędzie, które wykorzystali do opisywania każdego przypadku ludzkiej nieskuteczności w sferze gospodarczej w kategoriach nieracjonalności będącej wynikiem niedostatecznego wysiłku, braku zaangażowania czy wprost lenistwa. Dzięki tej perspektywie interpretacyjnej usunęli z pola widzenia takie sytuacje, gdy jednostka ze względów strukturalnych nie ma szans odnoszenia sukcesów lub chociażby samego uczestniczenia w wolnym rynku. Zewnętrznym wobec jednostki warunkiem wystarczającym do powodzenia w tej sferze jest bowiem dla liberałów sam fakt istnienia swobody gospodarowania, dlatego każde niepowodzenie mogą opisywać jako zawinione. 
Powiązanie swobody gospodarowania na wolnym rynku z wolnością jednostkową liberałowie argumentują tezą o tym, że wolny handel spowodował przełamanie społecznych barier i zniósł poddaństwo (Rand 2003: 237-238), ponieważ dostarczył bodźców do oddzielenia zdolności produkcyjnej od innych cech człowieka (Friedman 1993: 105-106). Dzięki temu ludzie mogą ze sobą współpracować w sferze ekonomicznej, niezależnie od dzielących ich światopoglądów, poglądów religijnych czy politycznych, gdyż motywuje ich do tej współpracy perspektywa wzajemnej korzyści.

Wzajemna korzyść, odnoszona podczas wymiany na wolnym rynku jest zatem, zdaniem liberałów, również podstawą nawiązywania więzi społecznych. „Człowiek (...) prawie ciągle potrzebuje pomocy swoich bliźnich i na próżno szukałby jej jedynie w ich życzliwości. Jest bardziej prawdopodobne, że nakłoni ich do pomocy, gdy potrafi przemówić do ich egoizmu i pokazać im, że jest dla nich samych korzystne, by zrobili to, czego od nich żąda" (Smith 1954: 21). Są to jednak więzi mocowane w egoizmie, w grze interesów, potrzeb i pragnień, które jednostki starają się zaspokoić przy pomocy innych jednostek po to, by finalnie uzyskać od nich całkowitą niezależność. W tym sensie uniezależnianie się od innych, dążenie do samowystarczalności ujmujemy jako odspołeczną strategię radzenia sobie z biedą, taką, która ze swej istoty nie sprzyja nawiązywaniu i podtrzymywaniu pozaekonomicznych relacji między ludźmi.

$\mathrm{W}$ analizowanych wypowiedziach kobiet uczestniczących w wymianie barterowej udało się nam zidentyfikować takie wypowiedzi, w których wykorzystując zaimki: ja, moje - nawiązują one do kwestii autonomii, niezależności od innych, samodzielności. Reguła wzajemności jest wówczas przez nie interpretowana jako społecznie ustanowiony sposób na zrewanżowanie się za doświadczane dobro, wyrównywanie rachunków czy spłacanie zaciągniętego długu (Caldini 2015: 36-37). W kontekście tych interpretacji relacje międzyludzkie nabierają dla nich charakteru instrumentalnego, rzeczowego i sformalizowanego. Ograniczają się bowiem do wymiany podporządkowanej zasadzie: „coś za coš”, „, nie ma niczego za darmo”, „za wszystko trzeba zapłacić”, „przysługa za przysługę”. Wymiana dokonująca się w jej cieniu sprzyja strategiom odspołecznym, ponieważ rewanż uwalnia uczestników wymiany od wzajemnej relacji, od więzi, która się wytworzyła i którą zrywa zaspokojenie wierzyciela. Ludzie odwzajemniając dar odzyskują balans w relacjach $\mathrm{z}$ innymi i skutecznie pozbywają się ciężaru zaciągniętego długu. Szacunek dla samego siebie jest wówczas budowany na niezależności od innych, na braku zobowiązań wobec nich (,ja im coś dam, to od nich za to coś dostanę, bo dla każdej najważniejsze to, żeby nic nikomu nie być winna"). Ten kontekst interpretowania wymiany barterowej osadza relacje międzyludzkie na osi my (biedni) - oni (niebiedni), w odniesieniu do której cały wysiłek badanych kobiet koncentruje się na przejściu ze sfery aktualnego „my” do sfery pożądanego „oni” („robienie czegoś dla kogoś daje 
taką szansę, że chociaż przez chwile biedny człowiek czuje się jak człowiek taki zwyczajny, taki normalny, a nie jak taki człowiek gorszej kategorii”) (Appadurai 2009: $55-57)^{3}$. Skutecznie uniemożliwia to zakwestionowanie ukonstytuowanej opozycji w kierunku równości pozycji. Rewanżowanie się jest zatem traktowane jako sposób na uwolnienie się od zagrażającego piętna/stygmy (Heatherton et al. 2008: 25-27, $126-128,226)^{4}$ niesamodzielności, uzależnienia od innych („to po to zaraz też coś daję, jak coś dostanę, żeby widzieli, że się po prostu wymieniamy, jak inni, a nie, że wiszę tylko na pomocy innych. Jak się odwdzięczę, to jest na czysto i mogę śmiało patrzeć innym w oczy; no i po to daję, żeby nie mówili, że sama nie dam rady i żeby nie czuć się gorszą od innych").

W tym ujęciu kluczowa z punktu widzenia konstruowania szacunku dla samego siebie i pozyskiwania szacunku innych jest samodzielność i niezależność od innych:

Ja to zawsze tak mam, że jak najszybciej chcę się odwdzięczyć, bo inaczej to ciągle o tym myślę. Szczególnie jak widzę tą osobę, to jej tak prosto w twarz nie mogę spojrzeć, bo mi głupio. Bo ja potrzebuję najzwyczajniej w świecie potwierdzenia, że coś jestem warta, że jestem w stanie sobie poradzić sama, mimo że nie mam pieniędzy. Póki tylko brałam, to czułam się człowiekiem takim niepełnym, nie w stu procentach. Każdy chce być niezależny, a to tylko tak można. (Respondentka 2)

A to się zawsze jakoś udaje, bo to się coś samemu zbierze, jakoś człowiek sobie może poradzić, jak oczywiście chce, a ja chcę i robię, co mogę i co umiem, byle tylko nie musieć liczyć na innych i nie iść po prośbie. (Respondentka 6)

Dla mnie to najważniejsze, żeby sobie samej radzić, bo jak mogę się odwdzięczyć, to tak, jakbym wyrównała rachunki i nie miała długu. Wtedy wiem, że jeszcze jestem coś warta, bo sama sobie daję radę, bo nie mam długów. (Respondentka 4)

Jak coś od kogoś dostaję, a potem mu coś daję, ale to nie są pieniądze, to pozwala mi, żeby tak mocno nie odczuwać, że jestem... co tu dużo ukrywać... nie odczuwać wtedy, że jestem biedna i nie daję sobie sama rady. (Respondentka 3)

\section{Konkluzje}

Powracając do przyjętej na początku teoretycznej ramy naszego wywodu, warto przypomnieć, że w interpretacji Sennetta szacunek do samego siebie i innych

\footnotetext{
Konstruowanie relacji międzyludzkich na opozycji my-oni jest zdaniem Arjuna Appaduraia fundamentalne dla tworzenia, niezmiernie niebezpiecznej społecznie, polityki gniewu.

4 Piętno/stygma stanowi rodzaj społecznego konstruktu, który pozwala na przypisanie i oznakowanie odmienności, a następnie dewaluowanie osoby/osób będących jej nosicielami/reprezentantami. Piętno powoduje, że człowiek jest postrzegany i sam postrzega siebie jako istotę niepełną, niepełnowartościową, gorszą, co sprzyja jego odsuwaniu/odsuwaniu się zwykłych kontaktów społecznych.
} 
może być konstruowany na podłożu dyskursu odwzajemnienia lub dyskursu samowystarczalności. Pierwsza strategia jest zakorzeniona w tradycjach i rytuałach gospodarki przedpieniężnej, druga natomiast nawiązuje do klasycznej liberalnej wykładni, zgodnie z którą człowiek „powinien się cieszyć uznaniem ze względu na swoją niezależność” (Sennett 2012: 112). W kontekście analizowanych wypowiedzi kobiet uczestniczących w wymianie barterowej obydwie strategie zdają się aktywne i kształtują ich myślenie o sobie i świecie. Co ciekawe, respondentki nie traktują ich jako wzajemnie sprzecznych czy też prowadzących do odmiennych konsekwencji społecznych, ale jako równoległe, prawomocne sposoby wyjaśniania praktyk, w których biorą udział. Tym samym, wbrew liberalnej wykładni tożsamości, przyjmują, że „ludzie dorośli mają prawo być zależni od innych” (Sennett 2012: 267), a równocześnie, pomimo pozytywnego waloryzowania tradycji wzajemnej wymiany, same pragną jednak uniezależnienia się od innych.

Bibliografia

Appadurai A., 2009, Strach przed mniejszościami. Esej o geografii gniewu, tłum. M. Bucholc, Warszawa: Wydawnictwo Naukowe PWN.

Olivier B., 2009, Communication in the era of "Empire" and "multitude". Philosophy and Communication. Collected essays, London-Frankfurt: Peter Lang Academic Publishers.

Carole T., Carole W., 1995, Psychologia. Podejścia oraz koncepcje, tłum. J. Gilewicz, Poznań, Wydawnictwo Zysk i S-ka.

Cialdini B.R., 2015, Wywieranie wpływu na ludzi. Teoria i praktyka, tłum. B. Wojciszke, Gdańsk: Gdańskie Wydawnictwo Psychologiczne.

Friedman M., współpr. R. Friedman, 1993, Kapitalizm i wolność, tłum. M. Lasota, Kondratowicz, Warszawa: Wydawnictwo Centrum im. Adama Smitha i „Rzeczpospolita”.

Gruszecki T., 2004, Teoria pieniądza i polityka pieniężna rys historyczny i praktyka gospodarcza, Kraków: Oficyna Ekonomiczna.

Heatherton T.F., Kleck R.E., Hebl M.R., Hull J.G. (red.), Społeczna psychologia piętna, 2008, Warszawa: Wydawnictwo Naukowe PWN.

Kant I., 2000, Co to jest Oświecenie [w: Z. Kuderowicz, Kant, Warszawa: Wiedza Powszechna.

Kudlińska I., 2012, Stygmatyzacja społeczna jako strategia dyskursywna biedy i jej rola $w$ procesie wykluczania społecznego, Kultura i Społeczeństwo, nr 1, http://yadda.icm. edu.pl//yadda/element/bwmeta1.element.hdl_11089_456/c/kudlinskaFolia_Sociologica_38.pdf (dostęp: 10.12.2015).

Lets, lets.pl/korzyści.html (dostęp: 15.01.2015).

Luttwak E., 2000, Turbokapitalizm. Zwycięzcy i przegrani światowej gospodarki, tłum. E. Kania, Wrocław: Wydawnictwo Dolnośląskie.

Palska H., Ludzie „w opiece”. Przyjmowanie darów i zaciaganie dtugów jako element stylu życia ubogich [w:] E. Tarkowska (red.), Zrozumieć biednego. O dawnej i obecnej biedzie w Polsce, http://otworzksiazke.pl/images/ksiazki/zrozumiec_biednego/zrozumiec_biednego.pdf (dostęp: 14.07.2017).

Piotrowska A., 2014, Bitcoin a definicja i funkcje pieniądza, Annales Universitatis Mariae Curie-Skłodowska. Sectio H, Oeconomia, nr 48(3), http://bazhum.muzhp.pl/media// 
files/Annales_Universitatis_Mariae_Curie_Sklodowska_Sectio_H_Oeconomia/Annales_Universitatis_Mariae_Curie_Sklodowska_Sectio_H_Oeconomia-r2014-t48-n3/Annales_Universitatis_Mariae_Curie_Sklodowska_Sectio_H_Oeconomia-r2014-t48-n3s275283/Annales_Universitatis_Mariae_Curie_Sklodowska_Sectio_H_Oeconomia-r2014-t48-n3-s275-283.pdf (dostęp: 21.03.2017).

Rand A., 2003, Rasizm [w:] idem, Powrót człowieka pierwotnego. Rewolucja antyprzemysłowa, tłum. Z.M. Czarnecki, Poznań: Zysk i S-ka.

Reichel J., 2007, Lokalny recykling pieniądza, Kraków: Zielone Brygady.

Sennett R., 2012, Szacunek w świecie nierówności, tłum. J. Dzierzgowski, Warszawa: Warszawskie Wydawnictwo Literackie MUZA SA.

Smith A., 1954, Badania nad natura i przyczynami bogactwa narodów, t. 1, tłum. G. Wolff, O. Eifeld, Z. Sadowski, A. Prejbisz, B. Jasińska, Warszawa: PWN.

Szkudlarek T., 2005, „Koniec pracy” czy koniec zatrudnienia? Edukacja wobec presji światowego rynku [w:] A. Kargulowa, S.M. Kwiatkowski, T. Szkudlarek (red.), Rynek i kultura neoliberalna a edukacja, Kraków: Oficyna Wydawnicza „Impuls”.

Wewiór P., Jurkiewicz J., 2013, Alternatywna deska ratunku, http://nowyobywatel. pl/2013/07/26/alternatywna-deska-ratunku/ (dostęp: 21.03.2017). 